\title{
Garnasmokkun hjá börnum á Íslandi
}

Kristín Pétursdóttir ${ }^{1}$ læknanemi, Práinn Rósmundsson ${ }^{1,2}$ læknir, Pétur H. Hannesson ${ }^{1,3}$ læknir, Páll Helgi Möller ${ }^{1,4}$ læknir

\section{ÁGRIP}

Inngangur: Garnasmokkun kallast pað pegar hluti af görn smokrast inn í sjálfa sig og er algengasta ástæða garnastíflu hjá börnum á aldrinum priggja mánaða til priggja ára. Tilgangur rannsóknarinnar var að kanna nýgengi, aldur, kyn og einkenni garnasmokkunar hjá börnum á Íslandi, greiningartækni, árangur meðferðar, endurkomu og dánartíðni.

Efniviður og aðferðir: Rannsóknin var afturskyggn par sem safnað var gögnum úr sjúkraskrám barna sem höfðu fengið garnasmokkun á Íslandi á 25 ára tímabili (1986-2010). Sjúklingar voru fundnir með pví að leita í rafrænu sjúkraskrárkerfi Landspítala og Sjúkrahússins á Akureyri.

Niðurstöður: Alls greindust 67 börn með garnasmokkun á tímabilinu, 44 drengir (66\%) og 23 stúlkur (34\%). Börnin voru á aldrinum priggja mánaða til 11 ára (miðgildi 8 mánuðir). Nýgengi garnasmokkunar var 0,4 tilfelli á hver 1000 börn yngri en eins árs. Garnasmokkunin var algengust á mótum smágirnis og ristils og var staðsett par í $94 \%$ tilvika og í $70 \%$ tilvika var orsökin ópekkt. Helsta greiningaraðferðin var skuggaefnisinnhelling um endaparm sem var jafnframt helsta meðferðarúrræðið. Hlutfall skuggaefnisinnhellinga par sem leiðrétting tókst var $62 \%$. Tæplega helmingur barnanna gekkst undir skurðaðgerð og var framkvæmt hlutabrottnám á görn hjá 6 börnum eða $9 \%$ allra sjúklinganna. Prjú börn eða $4 \%$ fengu endurtekna garnasmokkun.

Ályktanir: Árangur meðferðar við garnasmokkun er góður á Íslandi en æskilegt er að snúa við peirri próun sem hér sést, að innhellingum sé að fækka og skurðaðgerðum að fjölga á rannsóknartímanum.
Læknadeild Háskóla Íslands, ${ }^{2}$ barnaskurðdeild,

myndgreiningadeild og ${ }^{4}$ skurðlækningadeild Landspítala.

Fyrirspurnir: Páll Helgi Möller pallm@landspitali.is

Greinin barst 10. september 2012, sambykkt til birtingar 16. janúar 2012.

\section{Inngangur}

Garnasmokkun (intussusception) er ástand sem myndast pegar garnahluti smokrast inn í aðliggjandi hluta garnarinnar. Pó að garnasmokkun sé ekki algengt sjúkdómsástand er pað algengasta ástæða garnastíflu hjá börnum á aldrinum priggja mánaða til priggja ára. Garnasmokkun veldur bláæðastasa og bjúg og ef ástandið er ekki greint og meðhöndlað getur pað leitt til lokunar slagæða, dreps og rofs á görn. ${ }^{1}$

Hjá ungum börnum er garnasmokkun oftast staðsett á mótum smágirnis og ristils og er orsök hennar ópekkt í um 90\% tilvika. Talið er að stækkaður eitilvefur vegna sýkingar og bólgu sé orsökin í mörgum pessara tilfella. ${ }^{1}$ Í einungis 10\% tilvika er ástæðan pekkt og er pá oftast um að ræða „leiðandi punkt“ í parmaveggnum sem dregur garnasmokkunina áfram en líkurnar á pví aukast með aldri. ${ }^{2}$ Раð eru margar vel pekktar ástæður fyrir „leiðandi punkti“. Helstar eru: Meckels-sarpur (Meckel's diverticulum), garnasepar, góðkynja og illkynja æxli. Ýmsir undirliggjandi sjúkdómar geta aukið hættuna á garnasmokkun, eins og Henoch Schönlein purpura, slímseigjusjúkdómur (cystic fibrosis) og Peutz-Jeghersheilkenni. ${ }^{1}$

Mikill munur er á nýgengi milli landa. Nýgengi í Evrópu er 0,4-2,2 tilfelli á hver 1000 börn yngri en eins árs., ${ }^{3,4}$ Garnasmokkun getur komið fyrir á hvaða aldri sem er en fjöldi tilfella nær hámarki milli 5 og 9 mánaða og einungis $10-25 \%$ tilfella koma fyrir eftir tveggja ára aldur. ${ }^{1}$ Um $60-70 \%$ tilfella finnast hjá drengjum en orsök pess er ekki pekkt.1,2,5

Hjá flestum börnum undir tveggja ára aldri með hefðbundna garnasmokkun á mótum smágirnis og ristils er klíníska myndin skyndilegir kveisukenndir kviðverkir og uppköst sem með tímanum verða galllituð., ${ }^{2,6}$ Kviðverkjaköstin standa yfirleitt yfir í nokkrar mínútur með 10-20 mínútna hléum. ${ }^{7}$ Á milli kasta getur barnið verið algjörlega einkennalaust. ${ }^{2}$ Önnur einkenni eru blóð í hægðum sem getur verið eins og rautt slím blandað hægðum, pylsulaga fyrirferð í efri hægri fjórðungi eða á uppmagálssvæði (epigastrium), paninn kviður, lost og lífhimnubólga. ${ }^{1,6}$

Kviðaryfirlit er að jafnaði fyrsta rannsókn hjá pessum sjúklingum og er notuð til að útiloka rof á görn og til greiningar á garnastíflu. Víða er skuggaefnisinnhelling um endaparm hefðbundin rannsókn til greiningar á garnasmokkun hjá börnum og er aðferðin jafnframt notuð til að meðhöndla sjúkdóminn. Ómun er nú einnig notuð til greiningar á mörgum sjúkrastofnunum. ${ }^{8}$

Ef ekki tekst að leiðrétta garnasmokkunina með skuggaefnisinnhellingu parf að framkvæma skurðaðgerð par sem hún er leiðrétt og leiðandi punktur fjarlægður sé hann til staðar. Einnig parf aðgerð ef grunur er um drep eða rof á görn. ${ }^{2}$

Dauðsföll vegna garnasmokkunar eru nú orðin sjaldgæf í próuðum löndum en dánartíðni í mörgum vanpróuðum ríkjum er pó enn há, eða allt að 55\%.3.,5, Endurtekin garnasmokkun verður hjá um $4 \%$ barna. ${ }^{2}$

Aldrei áður hefur verið gerð rannsókn á faraldsfræði garnasmokkunar á Íslandi. Tilgangur rannsóknarinnar var að kanna faraldsfræðilega pætti sjúkdómsins hjá börnum hér á landi, svo sem nýgengi, aldur, kyn og einkenni. Einnig að kanna hvaða greiningartækni og meðferð var notuð, árangur greiningar og meðferðar, fylgikvilla, endurkomu, dánartíðni og bera niðurstöðurnar saman við erlendar rannsóknir. 


\section{Efniviður og aðferðir}

Gerð var afturskyggn rannsókn par sem safnað var gögnum úr sjúkraskrám barna sem greindust með garnasmokkun á Íslandi yfir 25 ára tímabil, eða frá 1. janúar 1986 til 31. desember 2010. Sjúklingar voru fundnir með pví að leita að ICD-greiningarnúmerum garnasmokkunar í rafrænu sjúkraskrárkerfi Landspítala og Sjúkrahússins á Akureyri. Meðferð garnasmokkunar er einungis veitt á pessum tveimur sjúkrastofnunum og pví má leiða að pví líkur að rannsóknin nái til allra barna á Íslandi sem greindust með sjúkdóminn á ofangreindu tímabili. Börn voru skilgreind sem einstaklingar undir 18 ára aldri.

Hver sjúkraskrá var yfirfarin til pess að staðfesta að um garnasmokkun væri að ræða. Í peim tilfellum par sem ekki var hægt að staðfesta garnasmokkun með myndgreiningarrannsóknum eða skurðaðgerð var tekin afstaða til sögu klínískra einkenna og sjúklingur annaðhvort útilokaður eða tekinn með í rannsóknina $(\mathrm{n}=7)$.

Alls fundust 79 tilfelli í tölvukerfum Landspítala og Sjúkrahússins á Akureyri með útskriftargreininguna garnasmokkun. Af peim voru 9 sjúklingar útilokaðir úr rannsókninni af eftirfarandi ástæðum; sjúkraskrá fannst ekki (n=1), ICD-greining var ekki rétt $(n=2)$ og grun um garnasmokkun var ekki hægt að staðfesta með myndgreiningarrannsókn, skurðaðgerð né klínískri greiningu $(n=6)$. Eftir stóðu pví 70 tilfelli garnasmokkunar hjá 67 börnum en prjú peirra fengu garnasmokkun tvisvar. Pessi endurteknu tilfelli voru útilokuð úr rannsókninni.

Pau atriði sem meðal annars voru skráð úr sjúkraskrám voru aldur, kyn, orsakir, rannsóknir og meðferð garnasmokkunar. Reiknað var aldursstaðlað nýgengi með mannfjöldatölum frá Hagstofu Íslands.

Skuggaefnisinnhelling var talin hafa tekist ef skuggaefni sást flæða inn í smágirni og/eða einkenni sjúklings hurfu við innhellinguna. Seinkuð greining var talin hafa átt sér stað ef börn voru greind seinna en á innlagnardegi.

Öll gögn voru skráð inn í tölvufærðan gagnagrunn. Lýsandi tölfræði var notuð til að lýsa rannsóknarpýðinu. Nafnabreytum var lýst með tölum og prósentum og pegar gerður var samanburður á hópum var notast við kí-kvaðratspróf. Notast var við línulega aðhvarfsgreiningu fyrir hlutföll pegar skoðað var hvernig meðferð próaðist yfir rannsóknartímabilið. Tölfræðileg marktækni var miðuð við $\mathrm{p}<0,05$.

Tafla I. Einkenni garnasmokkunar.

\begin{tabular}{lc} 
Kviðverkir & Fjöldi (\%) \\
\hline Uppköst & $41(61)$ \\
\hline Niðurgangur & $50(75)$ \\
\hline Óværð & $18(27)$ \\
\hline Blóð í hægðum & $25(37)$ \\
\hline Fyrirferð í kvið & $24(36)$ \\
\hline Hægðatregða & $10(15)$ \\
\hline Hiti $\geq 38,0^{\circ} \mathrm{C}$ & $2(3)$ \\
\hline Paninn kviður & $20(30)$ \\
\hline Uppköst og kviðverkir & $6(9)$ \\
\hline Prenning einkenna (kviðverkir, uppköst og blóð í hægðum) & $29(43)$ \\
\hline
\end{tabular}

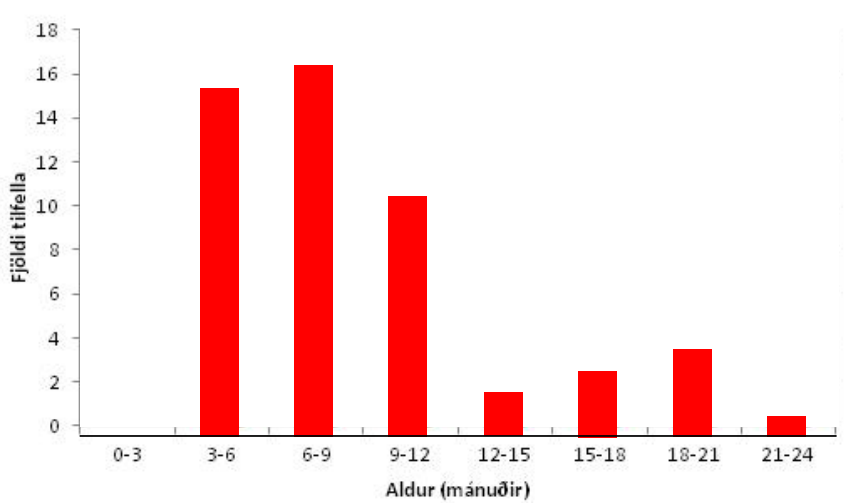

Mynd 1. Aldursdreifing barna undir tveggja ára aldri sem fengu garnasmokkun 19862010.

Áður en rannsóknin hófst fengust öll tilskilin leyfi frá Vísindasiðanefnd, Persónuvernd og framkvæmdastjórum lækninga við Landspítala og Sjúkrahúsið á Akureyri.

\section{Niðurstöður}

Alls fengu 67 börn garnasmokkun á tímabilinu, 44 drengir (66\%) og 23 stúlkur (34\%). Miðgildi aldurs var 8 mánuðir og var yngsta barnið priggja mánaða og pað elsta 11 ára. Flest börnin voru á fyrsta aldursári, eða $67 \%$, og komu $84 \%$ tilfella fram fyrir tveggja ára aldur (mynd 1). Einungis greindust fjögur börn eldri en fjögurra ára.

Nýgengi á rannsóknartímarbilinu (1986-2010) var að meðaltali 0,4 tilfelli á hver 1000 börn undir eins árs aldri.

Algengustu einkennin voru uppköst og kviðverkir. Klassísk prenning einkenna er talin vera kviðverkir, uppköst og blóð í hægðum og kom hún einungis fyrir í 18\% tilfella. Tíðni einkenna má sjá í töflu I.

Langflest tilfelli garnasmokkunar voru staðsett á mótum smágirnis og ristils eða 63 (94\%). Tvö tilfelli voru í smágirni en ekkert tilfelli í ristli. Í premur tilfellum var staðsetning garnasmokkunarinnar ópekkt.

Orsök garnasmokkunar var ópekkt hjá 47 börnum (70\%). „Leiðandi punktur" var til staðar hjá 20 börnum og voru peir allir góðkynja. Par af voru 11 börn með stækkaðan eitilvef sem greindur var við aðgerð. Sjá má orsakir og tíðni peirra í töflu II.

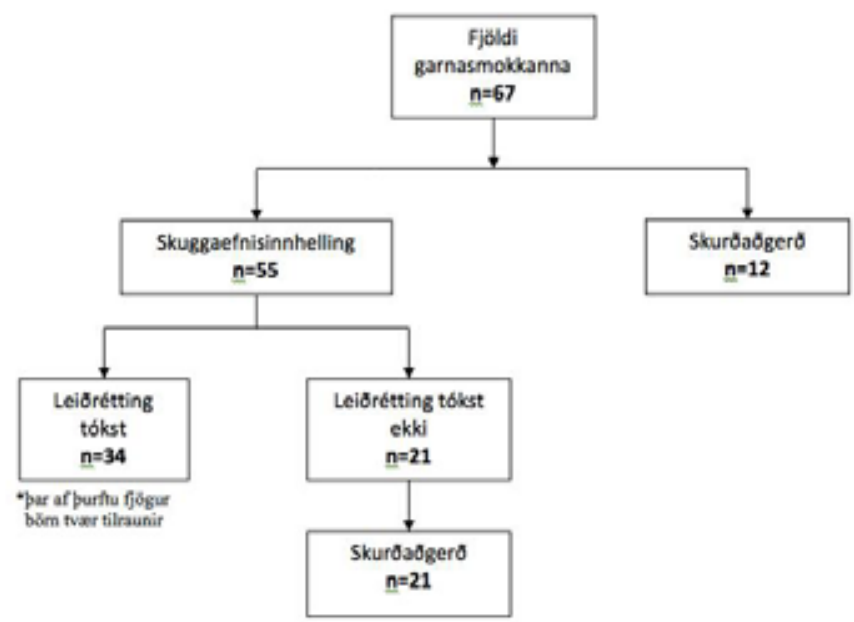

Mynd 2. Ferli meðferðar hjá börnum með garnasmokkun. 




Mynd 3. Hlutfall barna sem fór í skuggaefnisinnhellingu vegna garnasmokkunar.

Skuggaefnisinnhelling var oftast notuð til greiningar, eða hjá $82 \%$ barnanna, og ómun var notuð hjá $18 \%$ barnanna. Pessar rannsóknaraðferðir gátu hvor um sig staðfest greininguna í 75\% tilfella pegar pær voru notaðar (tafla III). Í engu tilfelli var loft notað við innhellingu. Kviðaryfirlit var notað hjá 75\% barnanna en í engu tilviki gat kviðaryfirlit staðfest greiningu garnasmokkunar. Rannsóknin var pó gagnleg og á 76\% kviðaryfirlita komu fram teikn sem gætu bent til garnasmokkunar, svo sem merki um garnastíflu. Aðrar rannsóknir sem notaðar voru hjá börnum voru tölvusneiðmynd, ristilspeglun og skuggaefnisrannsókn á smágirni (passage).

Í 7 tilfellum par sem grunur var um garnasmokkun hurfu einkenni eftir skuggaefnisinnhellingu án pess að sýnt hafi verið fram á hana og var pað talið staðfesta greininguna ásamt klassískum einkennum. Greining peirra barna var pví byggð á einkennum en ekki á myndgreiningarrannsóknum.

Skoða má ferli meðferðar á mynd 2. Alls fóru 55 börn (82\%) í skuggaefnisinnhellingu og par af var meðferðin árangursrík í $62 \%$ tilfella. Alls gengust 33 börn (49\%) undir opna skurðaðgerð. Annars vegar brátt $(n=12)$ og hins vegar í kjölfar skuggaefnisinnhellingar par sem ekki tókst að leiðrétta garnasmokkunina $(n=21)$. Hjá 6 börnum (9\%) purfti að framkvæma hlutabrottnám á görn. Hjá flestum barnanna var ástæða hlutabrottnáms fylgikvilli garnasmokkunar, svo sem drep og rof á görn en 5 börn fengu drep í görn og af peim fékk eitt rof á görn. Hjá einu barni var framkvæmt hlutabrottnám á görn vegna fyrirferðar.

Ekkert barn fékk rof á görn í kjölfar skuggaefnisinnhellingar. Ekkert barn lést vegna garnasmokkunar á rannsóknartímabilinu.

Hlutfall barna sem fór í innhellingu lækkaði jafnt og pétt yfir tímabilið úr 100\% fyrstu 5 árin í 63\% síðustu 5 árin. Nam lækkunin pví 1,9\% á ári ( $\mathrm{p}=0,0003$; 95\% öryggisbil: -0,015 - -0,02) (mynd

Tafla II. Orsakir garnasmokkunar.

\begin{tabular}{lc}
\hline & Fjöldi (\%) \\
\hline Ópekkt orsök & $47(70)$ \\
\hline Stækkaður eitilvefur & $11(16)$ \\
\hline Innverptur botnlangi & $1(1)$ \\
\hline Meckelssarpur & $5(7)$ \\
\hline Blaðra í garnavegg & $1(1)$ \\
\hline Briskirtilsvefur í görn & $1(1)$ \\
\hline Ofnæmispurpuri (Henoch Schönlein purpura) & $1(1)$ \\
\hline
\end{tabular}

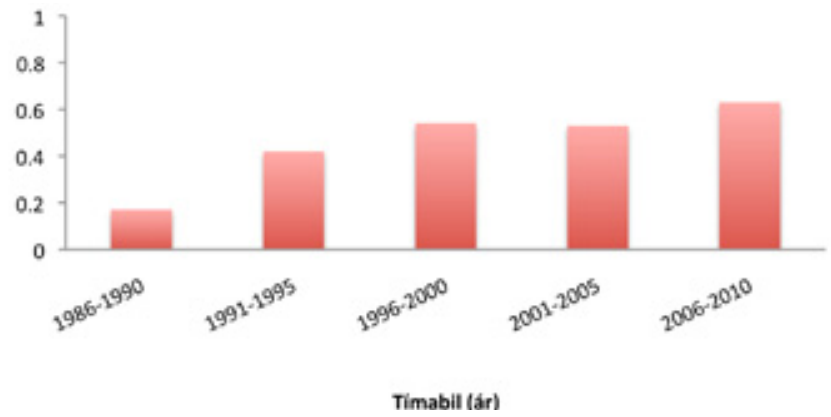

Mynd 4. Hlutfall barna sem fór í skurðaðgerð vegna garnasmokkunar.

Tafla III. Greiningaraðferðir.

\begin{tabular}{lcc}
\hline Greiningartækni sem var notuð & Fjöldi (\%) $^{\star}$ & Næmi \% \\
\hline Kviðaryfirlit & $50(75)$ & 0 \\
\hline Ristilinnhelling & $55(82)$ & 75 \\
\hline Ómun & $12(18)$ & 75 \\
\hline Annað & $9(13)$ & 56 \\
\hline
\end{tabular}

*Hlutfall af heildarfjölda sjúklinga (67).

*Annað: Tölvusneiðmynd, skuggaefnisrannsókn á smágirni (passage) og ristilspeglun.

3). Hlutfall barna sem fór í skurðaðgerð vegna garnasmokkunar á rannsóknartímabilinu jókst hins vegar úr 17\% fyrstu 5 árin í 62\% síðustu 5 árin, og nam aukningin pví 2\% á ári ( $\mathrm{p}=0,027 ; 95 \%$ öryggisbil: 0,004 - 0,037) (mynd 4). Ekki varð marktæk breyting á árangri innhellinga yfir tímabilið ( $\mathrm{p}=0,2 ; 95 \%$ öryggisbil: $-0,03$ -0,009) (mynd 5).

Börn greindust með garnasmokkun allt frá fyrsta til 20. dags innlagnar. Langflest börn, eða 79\%, greindust á innlagnardegi. Greining var seinkuð hjá 11 börnum (16\%), eða gerð á öðrum til 7. degi innlagnar. Prjú börn (4\%) sem greindust á 8 . til 20. degi innlagnar lágu inni vegna annars sjúkdómsástands en garnasmokkun próaðist á meðan á innlögn stóð. Ekki reyndist munur á pví hvaða meðferð börnin fengu, pað er skurðaðgerð eða skuggaefnisinnhellingu eingöngu, eftir pví hvenær börnin greindust en í báðum hópum var miðgildi greiningardags einn dagur.

Lengd sjúkrahúslegu var allt frá einum degi upp í 39 daga. Flest börn lágu inni í tvo daga en miðgildi sjúkrahúslegu voru fjórir dagar. Börn sem fóru í skurðaðgerð lágu lengur inni miðað við pau sem eingöngu fóru íinnhellingu, miðgildi 7 og prír dagar.

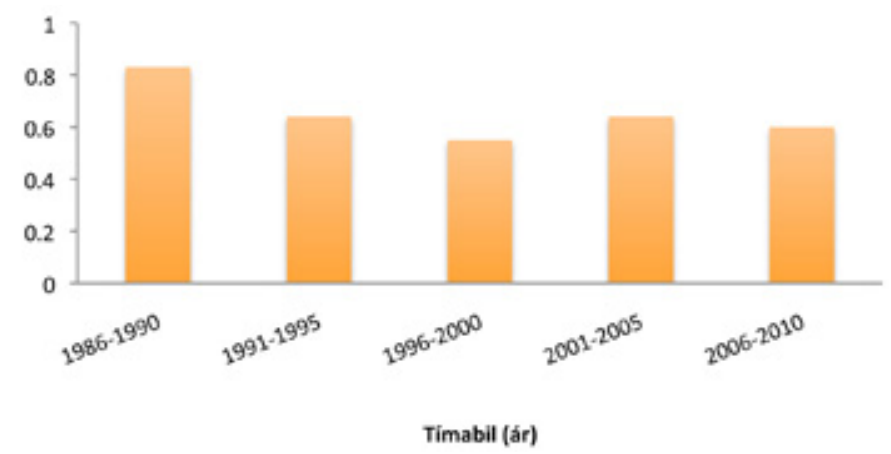

Mynd 5. Hlutfall innhellinga par sem tókst að leiðrétta garnasmokkunina. 
Prjú börn fengu endurtekna garnasmokkun á rannsóknartímabilinu og var endurkomutíðni pví 4,5\%.

\section{Umræða}

Pessi rannsókn staðfestir pað sem hefur komið fram í erlendum rannsóknum að garnasmokkun er algengust í ungum börnum og par eru drengir í meirihluta. ${ }^{1,5}$ Fjöldi tilfella var mestur á milli fjögurra og 10 mánaða aldurs og er petta svipað og sést í Evrópu (3-9 mánuðir) og í heiminum öllum (4-7 mánuðir). 3,5

Nýgengi garnasmokkunar er mjög mismunandi eftir löndum. Nýgengi á hver 1000 börn undir eins árs aldri er sambærilegt hér $(0,4)$ og í Evrópu og Bandaríkjunum $(0,4-2,2)$. $^{3-5,9}$

Einkenni garnasmokkunar á Íslandi eru pau sömu og lýst er í erlendum rannsóknum en algengustu einkennin voru uppköst og kviðverkir. ${ }^{5}$ Tíðni einkenna er hins vegar mjög mismunandi milli erlendra rannsókna og er líklegt að pað orsakist af mismunandi skráningu í sjúkraskrá. Hin klassíska prenning einkenna, kviðverkir, uppköst og blóð í hægðum, sem talin er hafa hátt forspárgildi fyrir garnasmokkun, kom einungis fyrir í 18\% tilfella og pví má ekki treysta á hana eingöngu. Pótt flest barnanna hafi verið greind á innlagnardegi var seinkun á greiningu hjá hluta peirra. Mjög mikilvægt er að greina garnasmokkun eins fljótt og auðið er svo hægt sé að koma í veg fyrir drep og rof á görn. Erlendar rannsóknir hafa sýnt fram á að seinkuð greining minnki árangur innhellinga og auki líkur á pví að sjúklingur fari í skurðaðgerð og gangist undir hlutabrottnám..$^{10}$ Einkenni geta verið ósértæk og óhefðbundin og verður að hafa pessa mismunagreiningu í huga við kviðverki hjá ungum börnum par sem garnasmokkun er algengasta orsök garnastíflu á aldrinum priggja mánaða og fram til priggja ára. ${ }^{1}$

Algengasta staðsetning garnasmokkunar á mótum smágirnis og ristils er í samræmi við erlendar rannsóknir., ${ }^{1,2}$

Orsök garnasmokkunar var ópekkt í tveimur priðju hluta tilfella og er pað í samræmi við pær erlendu rannsóknir par sem stækkaður eitilvefur er talinn með sem orsök, líkt og gert er í pessari rannsókn. ${ }^{5}$ Langalgengasta pekkta orsökin í pessari rannsókn var „leiðandi punktur" vegna stækkaðs eitilvefs sem sást í 16\% tilvika en næst algengasti „leiðandi punkturinn" var Meckelssarpur sem kom fyrir hjá 7\% barna og er petta í samræmi við aðrar rannsóknir. ${ }^{5}$

Í dag mæla margir höfundar með notkun ómunar til greiningar í stað skuggaefnisinnhellingar. ${ }^{8,11}$ Peir benda á hátt næmi og sértækni rannsóknarinnar, hún feli ekki í sér inngrip og útsetji sjúklinginn ekki fyrir jónandi geislun. Auk pess að greina garnasmokkun getur ómun einnig greint „leiðandi punkt" og annað sjúkdómsástand sem er ótengt garnasmokkun.,8 Í pessari rannsókn var skuggaefnisinnhelling langoftast notuð sem greiningaraðferð, eða í 82\% tilfella, en ómun var einungis notuð hjá $18 \%$ barna. Petta vekur spurningu um hvort ómun sé vannýtt sem greiningaraðferð hér á landi. Ómun hefur pó pann galla að röntgenlæknir með reynslu af rannsókninni parf að vera aðgengilegur allan sólarhringinn, par sem árangur ómunar er sérstaklega háður peim sem framkvæmir hana. ${ }^{8}$ Pessar bjargir hafa ekki verið til staðar á Íslandi á rannsóknartímanum og par sem einungis fá tilfelli garnasmokkunar greinast á ári á Íslandi er ekki víst að nægileg reynsla skapist til pess að rannsóknaraðferðin nái fullu greiningargildi sínu.

Hægt er að nota nokkrar aðferðir til meðhöndlunar sjúkdómsins. Hér á landi er notast við innhellingu með baríumskuggaefni. Leiðrétting með loftprýstingi hefur ekki verið notuð hér á landi en pessi aðferð hefur ýmsa kosti og er víða notuð. Aðferðin er fljótvirk með stuttum gegnumlýsingartíma og pví lægri geislaskammti en innhelling með skuggaefni. ${ }^{8}$ Notkun ómstýrðrar saltvatnsinnhellingar er að aukast í Evrópu. Helsti kostur pessarar aðferðar er að sjúklingur verður ekki fyrir geislun. Pví mæla margir með henni pví æskilegt er að takmarka geislaskammt hjá börnum. ${ }^{8}$ En líkt og pegar notast er við ómun til greiningar er árangurinn háður peim sem framkvæmir rannsóknina. ${ }^{8}$

Árangur leiðréttingar með baríuminnhellingu er svipaður og sýnt hefur verið fram á með öðrum aðferðum, pað er loftinnhellingu í gegnumlýsingu eða ómstýrðri saltvatnsinnhellingu. ${ }^{8}$ Hér á landi eru tilfelli tiltölulega fá og óvíst hvort ástæða er til að taka upp nýjar aðferðir par sem óvissa um árangur fylgir pví að taka upp nýja aðferð í stað gamalreyndrar aðferðar.

Í pessari rannsókn var skuggaefnisinnhelling fyrsta meðferð hjá stærstum hluta barnanna (82\%) og var hún árangursrík í 62\% tilvika. Petta er innan peirra marka sem sést hafa erlendis par sem árangurinn er mjög mismunandi (55-90\%) og notast er við mismunandi aðferðir við innhellinguna. ${ }^{8}$ Tíðni skurðaðgerða er sömuleiðis mjög mismunandi erlendis og í nýlegri evrópskri yfirlitsgrein var hún 10-68\% en meðalskurðtíðnin var 19\%. ${ }^{3}$ Prátt fyrir að árangur innhellinga hér á landi sé innan pess sem víða sést, verður 49\% skurðtíðni að teljast hátt hlutfall og hlýtur pað að vera markmið okkar að ná betri árangri í greiningu og meðferð með fækkun skurðaðgerða. Skurðaðgerðir eru mun meira inngrip og endurspeglast pað í lengri legutíma peirra sem fóru í skurðaðgerð miðað við pá sem fóru eingöngu í innhellingu. Sú próun sem sést í pessari rannsókn, að innhellingum sé að fækka og skurðaðgerðum að fjölga, verður pví að teljast óæskileg. Skýringin á fjölgun skurðaðgerða á tímabilinu er ekki sú að árangur innhellinga sé að verða lakari, pví hann helst nokkuð jafn yfir tímabilið, heldur virðist orsökin vera að fleiri börn fari beint í aðgerð án undanfarandi innhellingar. Ástæður pessa eru ekki ljósar en skýringanna getur verið að leita í nokkrum samverkandi páttum. •að má velta pví fyrir sér hvort petta stafi af pví að áherslur barnaskurðlækna hafi breyst og hvort aukinnar tregðu gæti hjá röntgenlæknum til að framkvæma innhellingu. Hlutfall barna sem purftu að gangast undir hlutabrottnám á görn var ekki hærra en gerist annars staðar, еða $9 \% .3,9,10,12$

Fylgikvillar vegna garnasmokkunar voru drep og rof á görn en $9 \%$ barna fengu pessa fylgikvilla. Hins vegar fékk ekkert barn rof vegna skuggaefnisinnhellingar, sem styður áframhaldandi notkun peirrar meðferðar. Tíðni rofs vegna innhellingar í erlendum rannsóknum er á bilinu 0,4-0,7\% ${ }^{8}$

Í pessari rannsókn dó ekkert barn. Petta er í samræmi við pað sem sést annars staðar, en dánartíðni hefur farið lækkandi í próuðum löndum. ${ }^{3}$

Endurkomutíðni í pessari rannsókn var 4,5\% sem er svipað og sést erlendis. ${ }^{2}$

Kostur pessarar rannsóknar er að á Íslandi eru einungis tveir stórir spítalar sem eru búnir tækjum og pekkingu röntgenlækna 
og skurðlækna til að meðhöndla garnasmokkun. Pví ætti pessi rannsókn að ná til allra tilfella garnasmokkunar sem hafa komið upp hér á landi á umræddu tímabili. Veikleiki rannsóknarinnar er að hún er afturskyggn. Rannsóknin er pví háð peirri skráningu sem framkvæmd var í sjúkraskrá á hverjum tíma og er ekki um að ræða staðlaða skráningu.

\section{pakkarord}

Við pökkum Sigríði Pálu Konráðsdóttur ritara fyrir góða aðstoð. Kristján Pór Magnússon faraldsfræðingur fær bestu pakkir fyrir kennslu og góð ráð og Sigrún Helga Lund fyrir hjálp við tölfræðiúrvinnslu.

\section{Heimildir}

1. Waseem $M$, Rosenberg HK. Intussusception. Pediatr Emerg Care 2008; 240: 793-800.

2. Stringer MD, Pablot SM, Brereton RJ. Paediatric intussusception. Br J Surg 1992; 79: 867-76

3. Huppertz HI, Soriano-Gabarro M, Grimprel E, Franco E Mezner Z, Desselberger U, et al. Intussusception among young children in Europe. Pediatr Infect Dis J 2006; 25 (1 Suppl): S22-29.

4. Buettcher M, Baer G, Bonhoeffer J, Schaad UB, Heininger $\mathrm{U}$. Three-year surveillance of intussusception in children in Switzerland. Pediatrics 2007; 120: 473-80.
5. Bines JE IB. Acute Intussusception in Infants and Children: A Global Perspective. Vaccines and Biologicals. World Health Organization Department of Vaccines and Biologicals 2002.

6. Cera SM. Intestinal intussusception. Clin Colon Rectal Surg 2008; 21: 106-13

7. Le Masne A, Lortat-Jacob S, Sayegh N, Sannier N, Brunelle F, Cheron G. Intussusception in infants and children: feasibility of ambulatory management. Eur J Pediatr 1999; 158: 707-10.

8. del-Pozo G, Albillos JC, Tejedor D, Calero R, Rasero M, dela-Calle U, et al. Intussusception in children: current concepts in diagnosis and enema reduction. Radiographics 1999; 19: 299-319.
9. Tate JE, Simonsen L, Viboud C, Steiner C, Patel MM, Curns AT, et al. Trends in intussusception hospitalizations among US infants, 1993-2004: implications for monitoring the safety of the new rotavirus vaccination program. Pediatrics 2008; 121: e1125-1132.

10. Blanch AJ, Perel SB, Acworth JP. Paediatric intussusception: epidemiology and outcome. Emerg Med Australas 2007; 19: 45-50

11. Sorantin E, Lindbichler F. Management of intussusception. Eur Radiol 2004; 14 Suppl 4: L146-154.

12. Cochran AA, Higgins GL 3rd, Strout TD. Intussusception in traditional pediatric, nontraditional pediatric, and adult patients. Am J Emerg Med 2010; 29: 523-7.

\section{ENGLISH SUMMARY}

\section{Intussusception in children in Iceland}

Pétursdóttir K, Rósmundsson Th, Hannesson PH, Möller PH

Introduction: Intussusception occurs when a proximal portion of the bowel invaginates into the distal bowel. It is the most common cause of intestinal obstruction in children between 3 months and 3 years. This study aimed to assess patient profile, clinical presentation, diagnostic methods, treatment and outcome in children diagnosed with intussusception in Iceland.

Material and methods: We conducted a retrospective chart review of all children diagnosed with intussusception in Iceland during a 25 year period (1986-2010). Patients were identified from a medical record database in Iceland's two main hospitals, Landspítali and Akureyri Hospital. Results: A total of 67 children aged 3 months to 11 years (median age 8 months) were diagnosed with intussusception. Male to female ratio was 3:2. The mean incidence of intussusception was 0.4 cases per 1000 children $<1$ year old. Intussusception was idiopathic in $70 \%$ of patients and occurred in the ileocolic region in $94 \%$. Barium contrast enema was the most common diagnostic test. Barium enema reduction was attempted in $82 \%$ of patients and successful reduction rate was $62 \%$. Surgical treatment was required in $49 \%$ of patients and involved resection of bowel in $9 \%$. Three children had recurrent intussusception.

Conclusion: The results of treatment for intussusception in Iceland are good. The decline of enemas performed and the rise in surgical treatment observed over the study period is a reason for concern. In this regard there is room for improvement.

Key words: Intussusception, children, etiology, symptoms, treatment.

Correspondence: Páll Helgi Möller, pallm@landspitali.is

University of Iceland and Landspitali The National University Hospital of Iceland 